\title{
GENETIC AND METABOLIC DIVERSITY OF PINK-PIGMENTED FACULTATIVE METHYLOTROPHS IN PHYLLOSPHERE OF TROPICAL PLANTS
}

\author{
D. Balachandar; P. Raja; SP. Sundaram* \\ Department of Agricultural Microbiology, Tamil Nadu Agricultural University, Coimbatore, Tamil Nadu, India. \\ Submitted: June 19, 2007; Returned to authors for corrections: October 10, 2007; Approved: November 16, 2007.

\begin{abstract}
Diversity of Pink-Pigmented Facultative Methylotrophs (PPFMs) in phyllosphere of cotton, maize and sunflower was determined based on differential carbon-substrate utilization profile and Random Amplified Polymorphic DNA data. Results indicate that six diversified groups of PPFMs are found in these crops. Sunflower and maize phyllosphere harbor four different groups of methylobacteria while cotton has only two groups.
\end{abstract}

Key words: diversity; Methylobacterium; phyllosphere; PPFM; RAPD

Pink-Pigmented Facultative Methylotrophs (PPFMs) mostly belonging to the genus Methylobacterium are phylogenetically diverse and use one-carbon compounds such as formate, formaldehyde, methanol and as well as a wide range of multicarbon substrates as sole source of carbon and energy (5). They belong to a subgroup of Proteobacteria, order Rhizobiales and family Methylobacteriaceae. The unique feature of PPFMs is their ability to oxidize methanol, a methylotrophic property based on the presence of methanol dehydrogenase ( $m x a F)$ gene (2). Specifically, the genus Methylobacterium comprises 23 species isolated from a wide range of environments (4). While, PPFM bacteria on plant surfaces are benefited by methanol produced by plants (26), these bacteria secrete a variety of auxins (11) and cytokinins (15) that are utilized by the plants leading to an increased plant growth and yield. PPFMs have been reported to increase plant growth, germination, vigor index, yield and systemic resistance (16). Members of PPFM are ubiquitous in nature and found in a variety of habitats including phyllosphere, rhizosphere, root nodules, dust, freshwater, drinking water, lake sediments, etc (3,5). Methylobacterium spp. are common leaf epiphytes representing an important bacterial population on leaves (7) and are persistently present in the phyllosphere of numerous plants (8). Even though most of the PPFM species are reported to colonize plants of all regions, till now, no study has been undertaken on the diversity of PPFMs within and among the plant species. Thus, it gains significance to investigate the occurrence and distribution of natural populations of PPFMs and their dynamics in relation to different host plants.

Random amplified polymorphic DNA (RAPD) is a powerful molecular fingerprinting technique, which is highly discriminative and allows distinction even between closely related strains $(18,28)$. Methylobacteria could be discriminated at species level as they differ in range of carbon compounds utilizing pattern (27). In this study, we have explored the genetic and metabolic diversity of PPFM bacteria in the phyllosphere of cotton, maize and sunflower to reveal the heterogeneity of PPFMs within a single plant species and across different plant species using RAPD and differential carbon-substrate utilization profiling.

The PPFMs were isolated using $0.5 \%(\mathrm{v} / \mathrm{v})$ filter-sterilized methanol supplemented Ammonium Mineral Salts (AMS) medium (8) from the phyllosphere of cotton (cultivar MCU12), maize (cultivar Co2) and sunflower (cultivar Co3) exclusively raised for this study in the experimental plots of Tamil Nadu Agricultural University, Coimbatore, India. Ten plants of each crop were selected randomly at 30 days after sowing and $5^{\text {th }}$ and $7^{\text {th }}$ leaves of main stem were collected in sterile bags and PPFMs were isolated by leaf-imprinting technique as previously described (8). PPFM isolates were grown in methanol

*Corresponding Author. Mailing address: Department of Agricultural Microbiology, Tamil Nadu Agricultural University, Coimbatore 641 003, Tamil Nadu, India. Tel.: (+91) 422 6611294. E-mail: professorsundaram@yahoo.com 
supplemented AMS medium for 7 days at $30^{\circ} \mathrm{C}$ and genomic DNA was extracted by hexadecyltrimethyl ammonium bromide (CTAB) method as described by Ivanova et al. (10). The integrity and concentration of purified DNA was determined by agarose gel electrophoresis (24) and DNA concentration was adjusted to $20 \mathrm{ng} / \mu \mathrm{L}$ for PCR amplification.

The $m x a F$ gene in the isolates was detected with specific primers mxaf1003 (5'GCGGCACCAACT GGGGCTGGT3') and mxar1561 (5'GGG CAG CAT GAA GGG CTC CC3') (19). PCR reactions were carried out in Eppendorf master cycler, Germany in $40 \mu \mathrm{L}$ containing $50 \mathrm{ng}$ genomic DNA, $0.2 \mathrm{mM}$ dNTP mixture, $1 \mu \mathrm{M}$ primers, $2.5 \mathrm{mM} \mathrm{MgCl}_{2}$ and $2 \mathrm{U}$ Taq DNA polymerase (Bangalore Genei, India) under the following conditions: $95^{\circ} \mathrm{C}$ for $1 \mathrm{~min}$ followed by 35 cycles of $94^{\circ} \mathrm{C}$ for $1 \mathrm{~min}, 55^{\circ} \mathrm{C}$ for $2 \mathrm{~min}$, $72^{\circ} \mathrm{C}$ for $1 \mathrm{~min}$ and final extension at $72^{\circ} \mathrm{C}$ for $5 \mathrm{~min}$. PCR products were separated by electrophoresis on $1.5 \%$ agarose gels stained with ethidium bromide and documented in Alphaimager TM1200 documentation and analysis system.

Carbon substrate utilization profile of PPFM isolates was analyzed as described previously (13) in AMS medium substituted with different carbon compounds at $0.5 \%(\mathrm{w} / \mathrm{v})$ as presented in Table 1. The carbon substrate utilization pattern of the isolates were compared with that of standard species and grouped based on the similarity $(27,29)$. RAPD analysis was performed in 30 PPFM isolates using twenty different 10-base primers [OPM 1 (5'GTTGGTGGCT3'); OPM2 (ACAACGCCTC); OPM3 (GGGGGATGAG); OPM4 (GGCGGTTGTC); OPM5 (GGGAACGTGT); OPM6 (CTGGGCAACT); OPM7 (CCGT GACTCA); OPM8 (TCTGTTCCCC); OPM9 (GTCTTGCGGA); OPM10 (TCTGGCGCAC); OPQ1 (GGGACGATGG); OPQ2 (TCTGTCGGTC); OPQ3 (GGTCACCTCA); OPQ4 (AGTGC GCTGA); OPQ5 (CCGCGTCTTG); OPQ6 (GAGCGCCTTG); OPQ7 (CCCCGATGGT); OPQ8 (CTCCAGCGGA); OPQ9 (GG CTAACCGA) and OPQ 10 (TGTGCCCGAA)] as described by Guthrie et al., 1990 (6). The resulting polymorphic differences were analyzed using the program NTSYS-PC 2 by estimating the distance of PPFM isolates using Jaccard's Similarity Coefficient (12) and inferring the topology of the tree by the method of Clustering UPGMA (20). The indices of diversity, richness and evenness were calculated using the number of isolates belonging to each group based on carbon utilization pattern and RAPD profile. Diversity was calculated using the Shannon index: $H^{\prime}=-\Sigma^{S}\left[\left(n_{1} / n\right) \ln \left(n_{1} / n\right)\right]$, where $n_{1}$ is the number of isolates in each group and $n$ is the number of isolates in all groups (25). For richness, the Margalef index was used: $R=S-1 /$ $\ln (n)$, where $S$ in this case is the number of groups and $n$ is the number of isolates in all groups (17). The Pielou index was used as a measure of evenness: $E=H^{\prime} / \ln (S)$, where $H^{\prime}$ is the Shannon index and $S$ is the number of groups (23).

A total of sixty leaf samples, twenty each from cotton, maize and sunflower were analyzed for the diversity of PPFMs using differential carbon-substrate utilization pattern and RAPD-PCR

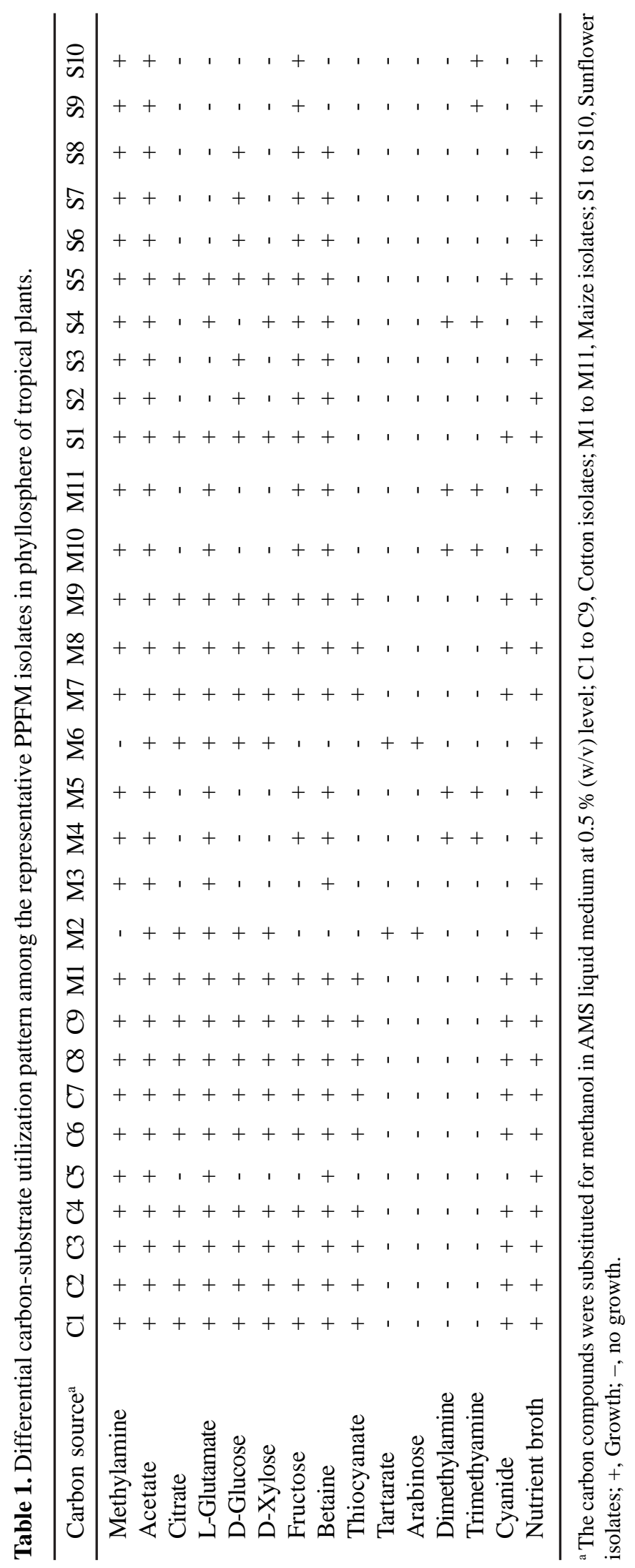


profiling. A total of 62 PPFMs isolated from three different crops' phyllosphere by leaf-impression technique were further authenticated for methylotrophy by PCR amplification of partial $m x a F$ gene using genomic DNA of the isolates. The results confirmed the ability of all the isolates to amplify about $550 \mathrm{bp}$ sized partial $m x a F$ gene.

The growth of PPFM isolates was recorded as presence or absence in AMS medium substituted with different carbon substrates and presented as Table 1. Carbon-substrate utilization profile of the isolates was exactly coincided with already reported species of Methylobacterium. When comparing the carbonsubstrate utilization profile of isolates with type strains of plant associated Methylobacterium, 62 isolates were clustered to six different groups (Table 2). Out of 62 isolates, 30 isolates (48.37\%) had similar profile of Methylobacterium thiocyanatum; 10 isolates $(16.13 \%)$ as M. aminovorans; 10 isolates $(16.13 \%)$ as M. suomiense; 4 isolate each of M. extorquens, M. fujisawaense and $M$. zatmanii $(27,29)$. Among the three tropical crop plants studied, sunflower and maize phyllosphere harbor four different groups of PPFMs, while cotton had only two types (Table 2).

Nearly $50 \%$ of the isolates ( 30 isolates) of PPFMs representing six different carbon-substrate utilization profiling and three different crop plants were analyzed for RAPD banding pattern. Among the twenty primers screened, seven RAPD primers (OPQ1, OPQ2, OPQ6, OPQ10, OPM3, OPM7 and OPM10) able to produce polymorphic amplicons were used for grouping the isolates. The representative banding pattern of primer OPQ10 was presented as Fig. 1. Dendrogram of combining metabolic

Table 2. Occurrence and distribution of PPFM isolates from phyllosphere of three different crop plants based on carbon utilization profiling.

\begin{tabular}{cccc}
\hline Crop & $\begin{array}{c}\text { Total number of } \\
\text { isolates }^{\mathrm{a}}\end{array}$ & $\begin{array}{c}\text { Representative isolates } \\
\text { selected for RAPD }\end{array}$ & $\begin{array}{c}\text { PPFM Species showing } \\
\text { similar C-profile }^{\mathrm{b}}\end{array}$ \\
\hline Cotton & 18 & $\mathrm{C} 1, \mathrm{C} 2, \mathrm{C} 3, \mathrm{C} 4, \mathrm{C} 6, \mathrm{C} 7, \mathrm{C} 8, \mathrm{C} 9$ & M. thiocyanatum \\
& 2 & $\mathrm{C} 5$ & M. extorquens \\
Maize & 8 & $\mathrm{M} 1, \mathrm{M} 7, \mathrm{M} 8, \mathrm{M} 9$ & M. thiocyanatum \\
& 8 & $\mathrm{M} 4, \mathrm{M} 5, \mathrm{M} 10, \mathrm{M} 11$ & M. aminovorans \\
& 4 & $\mathrm{M} 2, \mathrm{M} 6$ & M. fujisawaense \\
Sunflower & 2 & $\mathrm{M} 3$ & M. extorquens \\
& 10 & $\mathrm{~S} 2, \mathrm{~S} 3, \mathrm{~S} 7, \mathrm{~S} 8, \mathrm{~S} 6$ & M. suomiense \\
& 4 & $\mathrm{~S} 9, \mathrm{~S} 10$ & M. zatmanii \\
& 2 & $\mathrm{~S} 4$ & M. aminovorans \\
& 4 & $\mathrm{~S} 5, \mathrm{~S} 1$ & M. thiocyanatum \\
\hline
\end{tabular}

a The number of isolates showing similar carbon substrate utilization profile;

${ }^{\mathrm{b}}$ Carbon substrate utilization profile compared with key data of Jourand et al. (13) and VanAken et al. (27).

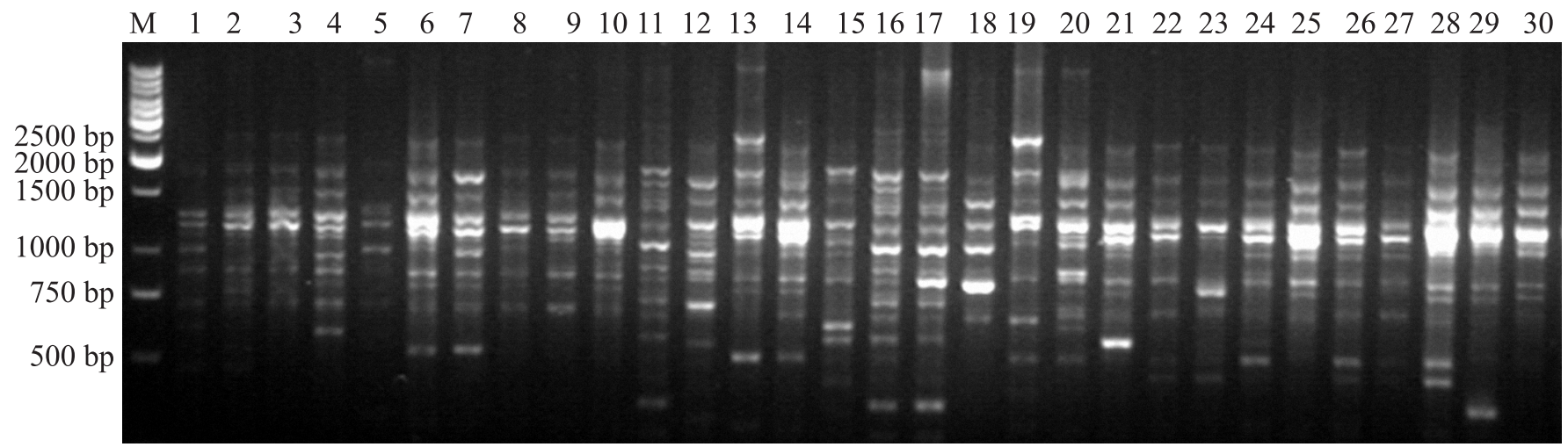

Figure 1. RAPD pattern of representative PPFM isolates from phyllosphere of three different crops generated by primer OPQ10. M - Marker DNA ladder (1 kbp); Lane 1 to 9 - Cotton isolates (C1-C9); Lane 10 to 20 - Maize isolates (M1-M11); Lane 21 to 30 Sunflower isolates (S1-S10). 
diversity data (presence or absence of growth in different carbon-substrates) and RAPD banding pattern (binary matrix recording presence or absence of band) of PPFM isolates revealed that the PPFM isolates are grouped into 5 different clusters (Fig. 2). Cluster A comprises of fourteen isolates (8 from cotton; 4 from maize and 2 from sunflower); cluster B comprises of 10 isolates (4 from maize and 6 from sunflower); cluster $\mathrm{C}$ includes one cotton isolate (C5) and one maize isolate (M3); cluster D with two sunflower isolates (S9, S10) and cluster E with two maize isolates (M2, M6). With reference to crop species, most of cotton isolates except $\mathrm{C} 5$ formed one cluster (A), maize isolates are present in clusters A, B, C and E, whereas the sunflower isolates are distributed in clusters A, B and D. The combining of both carbon-substrate utilization pattern and RAPD banding pattern increased the resolution of divergence of PPFM isolates, when comparing the individual data sets.

To quantify the PPFMs' diversity, the combined sets of carbon substrate utilization profile and RAPD banding pattern data were subjected to statistical analysis. Shannon index of diversity $\left(\mathrm{H}^{\prime}\right)$ which refers the number of species and evenness of the species was very low in cotton (0.32) compared to maize (1.26) and sunflower (1.22). Margalef index (R) specifically refers the species richness in PPFM community, which was also reported very low in cotton (1.67) and high in maize and sunflower (3.67 and 3.66 respectively). Pielou index referring the evenness of the species in a community was also recorded to be very low in cotton $(0.469)$. All the three diversity indices calculated for PPFM isolates in phyllosphere of these crop plants revealed that cotton leaves had narrow diversity while maize and sunflower with widely diversified PPFMs. On the basis of genetic and metabolic studies of the isolates, significant diversity was found among the PPFM isolates in phyllosphere of these crops. Great genotypic and metabolic diversity of PPFMs in phyllosphere revealed by this study is the fist kind of report in tropical crop plants. Higher degree of PPFMs' diversity in sunflower and maize leaves and low in cotton leaves reported

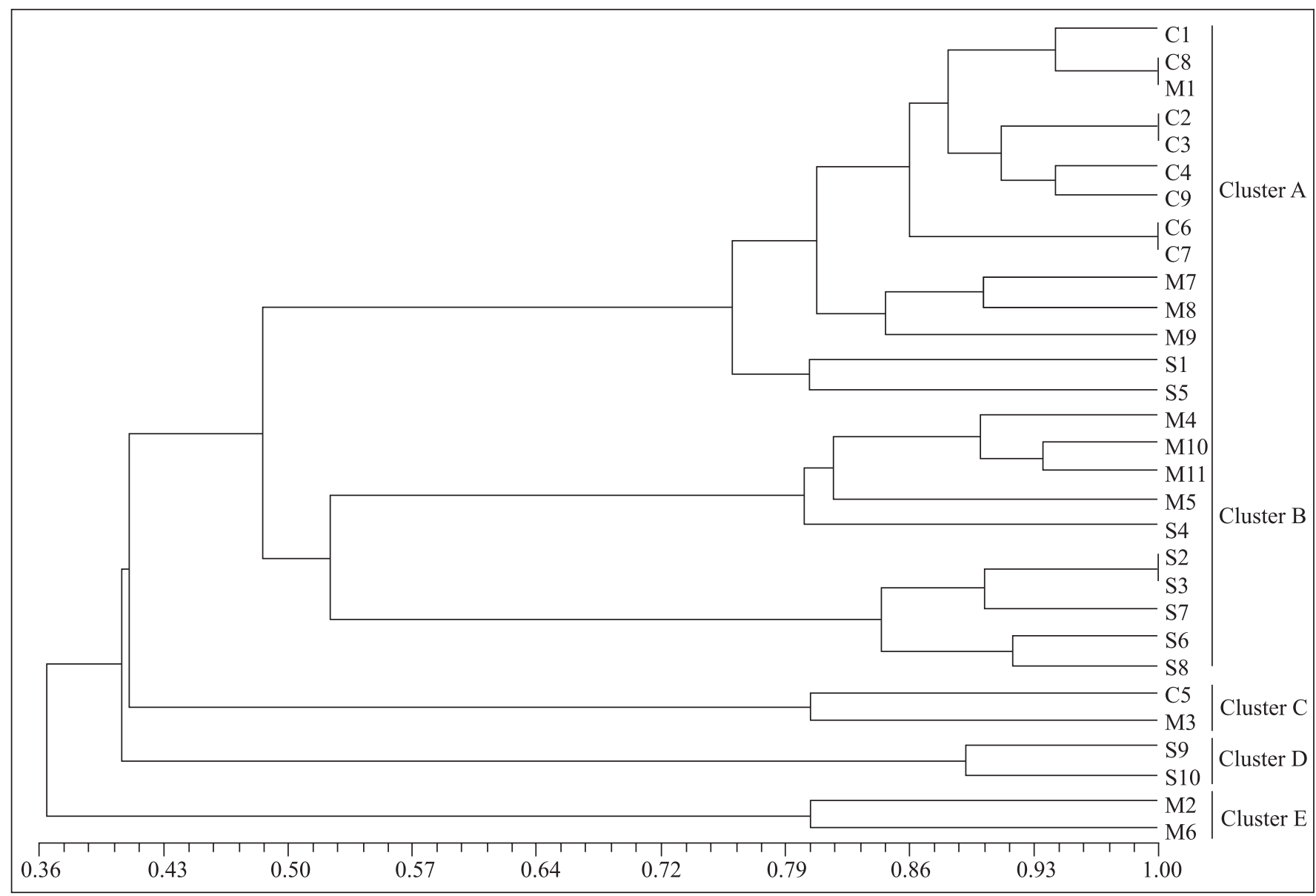

Figure 2. Dendrogram showing relatedness of 30 PPFM isolates based on Jaccard's similarity coefficient calculated using combined data of RAPD-PCR banding pattern and carbon-substrate utilization profile of isolates. 
in this study may be due to their differential emission of large variety of volatile compounds including methanol through leaves, which are to be studied thoroughly about the relationship of leaf emitting metabolites with PPFMs' diversity (21).

Recent findings have demonstrated that degree of plant PPFMs association varies as symbiotic (13), epiphytic (22) and as endophytic (14). These bacteria on phyllosphere produce cytokinins, auxins and vitamin B12 and stimulate the plant development (1). However, the over all nature of their relationship with plant is yet understood poorly and the biological significance of these bacterial species is still unknown. Under these circumstance, the diversity studies of PPFMs gain importance to understand the plant interactions. We have demonstrated the genotypic and metabolic diversity and community structure of PPFMs in different tropical plants' phyllosphere. Findings of this study indicate in depth molecular studies are needed to understand the diversity of methylobacteria in phyllosphere, as the leave metabolites influence the colonization (9). Further, detailed studies are necessary to explore the complexity of interaction between these PPFMs and host plants wherein a multitude of synergistic and antagonistic interactions are operative in the phyllosphere.

\section{RESUMO}

\section{Diversidade metabólica e genética de microrganismos metilotróficos facultativos pigmentados na filosfera de plantas tropicais}

A diversidade de microrganismos metilotróficos facultativos pigmentados (PPFMs) na filosfera de algodão, milho e girassol foi determinada baseada no perfil diferencial de utilização de substratos de carbono e em dados de RAPD. Os resultados indicaram a existência de seis grupos diferentes de PPFMs nessas plantas. As filosferas de girassol e milho apresentaram quatro grupos diferentes de metilobactérias enquanto a de algodão apresentou apenas dois grupos.

Palavras-chave: diversidade, Methylobacterium, filosfera, PPFM, RAPD

\section{REFERENCES}

1. Abanda-Nkpwatt, D.; Musch, M.; Tschiersch, J.; Boettner, M.; Schwab, W. (2006). Molecular interaction between Methylobacterium extorquens and seedlings: growth promotion, methanol consumption and localization of the methanol emission site. J. Exp. Bot., 57, 4025-4032.

2. Anthony, C.; Ghosh, M.; Blake, C.C. (1994). The structure and function of methanol dehydrogenase and related quinoproteins containing pyrralo-quinoline quinine. Biochem. J., 304, 665-674.

3. Corpe, W.A.; Rheem, S. (1989). Ecology of the methylotrophic bacteria on living leaf surfaces. FEMS Microbiol. Ecol., 62, 243250 .
4. Gallego, V.; Garcia, M.T.; Ventosa, A. (2006). Methylobacterium adhaesivum sp. nov., a methylotrophic bacterium isolated from drinking water. Int. J. Syst. Evol. Microbiol., 56, 339-342.

5. Green, P.N.; Bousifield, I.J. (1982). A taxonomic study of some Gram negative facultatively methylotrophic bacteria J. Gen. Microbiol., 128, 623-638.

6. Guthrie, P.A.I.; Magill, C.W.; Fredriksen, R.A.; Odyody, G.N. (1992). Random amplified polymorphic DNA markers: A system for identifying and differentiating isolates of Colletotrichum graminicola. Phytopathol., 82, 832-835.

7. Hirano, S.S.; Upper, C.D. (1991). Bacterial community dynamics. In: Andrews, J.H., Hirano, S.S. (eds). Microbial Ecology of Leaves, Springer, New York, p.271-294.

8. Holland, M.A; Polacco, J.C. (1994). PPFMs and other covent contaminants: Is there more to plant physiology than just plant. Annu. Rev. Plant Physiol. Plant Mol. Biol., 45, 197-208.

9. Hollond, M.A.; Long, R.L.G.; Polacco, J.C. (2002). Methylobacterium spp.: phylloplane bacteria involved in cross-talk with the plant host. In: Lindow, S.E., Elliot, V.J., Hechr-Poinar, E.I. (eds). Phyllosphere microbiology. American Phytopathological Society, St Paul, USA, p.125-135.

10. Ivanova, E.G.; Doronina, N.V.; Shepelyakovskaya, A.O.; Brovko, F.A.; Trotsenko, Y.A. (2000). Facultative and obligate aerobic methylobacteria synthesize cytokinins. Microbiol., 69, 646-651.

11. Ivanova, E.G.; Doronina, N.V.; Trotsenko, Y.A. (2001). Aerobic Methylobacteria are capable of synthesizing auxins. Microbiol., 70, 392-397.

12. Jaccard, P. (1912). The distribution of the flora in the alpine zone. New phytol., 11, 37-50.

13. Jourand, P.; Giraud, E.; Bena, G.; Sy, A.; Willems, A.; Gillis, M.; Dreyfus, B.; deLajudie, P. (2004). Methylobacterium nodulans sp. nov., for a group of aerobic, facultatively methylotrophic, legume root-nodule-forming and nitrogen-fixing bacteria. Int. J. Syst. Evol. Microbiol., 54, 2269-2273.

14. Lacava, P.T.; Araujo, W.L.; Marcon, J.; Maccheroni, W.; Azevedo, J.L. (2004). Interaction between endophytic bacteria from citrus plants and phytopathogenic bacteria Xylella fastidiosa causal agent of citrus-varigated chlorosis. Lett. Appl. Microbiol., 39, 55-59.

15. Lidstrom, M.E.; Chistoserdova, L. (2002). Plants in the pink: Cytokinin production by Methylobacterium. J. Bacteriol., 184, 1818.

16. Madhaiyan, M.; Poonguzhali, S.; Lee, H.S.; Hari, K.; Sundaram, S.P.; $\mathrm{Sa}, \mathrm{T}$. (2005). Pink-pigmented facultative methylotrophic bacteria accelerate germination, growth and yield of sugarcane clone Co86032 (Saccharum officinarum L.). Biol. Fertil. Soils, 41, 350-358.

17. Margalef, R. (1958). Information theory in ecology. Gen. Systems 3, 36-71.

18. Mazurier, S.I.; Audurier, A.; Marquet-Van der Mee, N.; Notermans, S.; Wernars, K. (1992). A comparative study of randomly amplified polymorphic DNA analysis and conventional phage typing for epidemiological studies of Listeria monocytogenes isolates. Res. Microbiol., 143, 507-512.

19. McDonald, I.R.; Kenna, E.M.; Murrell, J.C. (1995). Detection of methanotrophic bacteria in environmental samples with PCR. Appl. Environ. Microbiol., 61, 116-121.

20. Nei, M.; Li, W.H. (1979). Mathematical model for studying genetic variation in terms of restriction endonucleases. Proc. Natl. Acad. Sci. USA, 76, 5269-5273.

21. Nemecek-Marshall, M.; MacDonald, R.C.; Franzen, J.J.; Wojciechowski, C.L.; Fali, R. (1995). Methanol emission from leaves. Enzymatic detection of gas-phase methanol and relation of methanol fluxes to stomatal conductance and leaf development. Plant Physiol., 108, 1359-1368.

22. Omer, Z.S.; Tombolini, R.; Gerhardson, B. (2004). Plant colonization by pink-pigmented facultative methylotrophic bacteria (PPFMs). FEMS Microbiol. Ecol., 46, 319-326. 
23. Pielou, E.C. (1969). An introduction to mathematical ecology. John Wiley and Sons, London.

24. Sambrook, J.; Russel, D.W. (2000). Molecular cloning: A laboratory manual. Cold Spring Harbor Laboratory Press, New York.

25. Shannon, C.E.; Weaver, W. (1963). The mathematical theory of communication. University of Illinois Press, Urabana.

26. Sy, A.; Timmers, A.C.J.; Knief, C.; Garcia, N.; Willems, A.; deLajudie, P.; Prin, Y.; Neyra, M.; Gillis, M.; Boivin-Masson, C.; Dreyfus, B. (2005). Methylotrophic metabolism is advantageous for Methylobacterium extorquens during colonization of Medicago truncatula under competitive conditions. Appl. Environ. Microbiol., $71,7245-7252$
27. VanAken, B.; Peres, C.M.; Doty, S.L.; Yoon, J.M.; Schnoor, J.L. (2004). Methylobacterium populi sp. nov., a novel aerobic, pinkpigmented, facultatively methylotrophic, methane-utilizing bacterium isolated from poplar trees (Populus deltoides nigra DN34). Intl. J. Syst. Evol. Microbiol., 54, 1191-1196.

28. Williams, J.G.; Kubelik, A.R.; Livak, K.J.; Rafalski, J.A.; Tingey, S.V. (1990). DNA polymorphisms amplified by arbitrary primers are useful as genetic markers. Nucleic Acids Res., 18, 6531-6535.

29. Wood, A.P.; Kelly, D.P.; McDonald, I.R.; Jordan, S.L.; Morgan, T.D.; Khan, S.; Murrell, J.C.; Borodina, E. (1998). A novel pink-pigmented facultative methylotroph, Methylobacterium thiocyanatum sp. nov., capable of growth on thiocyanate or cyanate as sole nitrogen sources. Arch. Microbiol., 169, 148-158. 